\title{
Arctic sea ice export as a driver of deglacial climate
}

\author{
Alan Condron ${ }^{1 *}$, Anthony J. Joyce ${ }^{2}$ and Raymond S. Bradley ${ }^{2}$ \\ ${ }^{1}$ Geology \& Geophysics, Woods Hole Oceanographic Institution, Woods Hole, Massachusetts 02543, USA \\ ${ }^{2}$ Geosciences, University of Massachusetts at Amherst, Amherst, Massachusetts 01003, USA
}

\begin{abstract}
A widespread theory in paleoclimatology suggests that changes in freshwater discharge to the Nordic (Greenland, Norwegian, and Icelandic) Seas from ice sheets and proglacial lakes over North America played a role in triggering episodes of abrupt climate change during deglaciation (21-8 ka) by slowing the strength of the Atlantic Meridional Overturning circulation (AMOC). Yet, proving this link has been problematic, as climate models are unable to produce centennial-to-millennial-length reductions in overturning from short-lived outburst floods, while periods of iceberg discharge during Heinrich Event 1 (ca. 16 ka) may have occurred after the climate had already begun to cool. Here, results from a series of numerical model experiments are presented to show that prior to deglaciation, sea ice could have become tens of meters thick over large parts of the Arctic Basin, forming an enormous reservoir of freshwater independent from terrestrial sources. Our model then shows that deglacial sea-level rise, changes in atmospheric circulation, and terrestrial outburst floods caused this ice to be exported through Fram Strait, where its subsequent melt freshened the Nordic Seas enough to weaken the AMOC. Given that both the volume of ice stored in the Arctic Basin and the magnitude of the simulated export events exceed estimates of the volumes and fluxes of meltwater periodically discharged from proglacial Lake Agassiz, our results show that non-terrestrial freshwater sources played an important role in causing past abrupt climate change.
\end{abstract}

\section{INTRODUCTION}

The climate of the last deglaciation is marked by a series of abrupt changes in temperature. Of particular note is the Younger Dryas (YD) episode at ca. 12.9 ka that is often described as a millennial-length rapid return to glacial-like conditions over much of the North Atlantic region (Alley, 2000). While a variety of mechanisms have been proposed to explain this cooling, including a volcanic eruption, meteorite impact, and changes in atmospheric circulation (Wunsch, 2006; Firestone et al., 2007; Eisenman et al., 2009; Baldini et al., 2018), considerable research has postulated that the YD, and other periods of abrupt cooling such as the Preboreal Oscillation (PBO; ca. $11.3 \mathrm{ka}$ ) and the Older Dryas (ca. $14 \mathrm{ka}$ ), were triggered by variations in terrestrial meltwater discharge to the ocean (Broecker et al. 1989; Clark et al., 2001; Teller et al., 2002). For the YD, a major switch in North American glacial drainage patterns around this time

*E-mail: acondron@whoi.edu is thought to have routed meltwater from the Mississippi River to the St. Lawrence and/or Mackenzie Rivers so that it entered the ocean closer to sites of deep water formation that modulate the strength of the Atlantic Meridional Overturning circulation (AMOC) and its associated northward heat transport (Kennett and Shackleton, 1975; Manabe and Stouffer, 1995; Murton et al., 2010). In addition, freshwater discharge from the Fennoscandian Ice Sheet and/or Baltic Ice Lake may have played a role in triggering the initial onset of cooling (Muschitiello et al., 2016).

Nevertheless, unraveling the link between times of increased meltwater input and cooling remains difficult (Broecker, 2006; Renssen models is sensitive to small changes in freshwater forcing $\left(\sim 0.1 \mathrm{~Sv} ; \mathrm{Sv}=10^{6} \mathrm{~m}^{3} / \mathrm{s}\right.$; Stouffer et al., 2006), these models indicate that shortduration outburst floods-like the ones thought to have occurred as new drainage outlets periodically opened-would not have led to any longterm weakening of the large-scale AMOC and, as such, were unlikely to have caused centenet al., 2015). While the AMOC in most climate nial-to-millennial-length cooling (Meissner and Clark, 2006; Renssen et al., 2015). A sustained switch in the meltwater drainage route to the ocean - in response to a change in the position of the southern margin of the Laurentide ice sheet (LIS) - is also frequently hypothesized to have played a role in triggering deglacial cooling by altering the delivery of meltwater to sites of deep convection that regulate North Atlantic Deepwater (NADW) formation (e.g., Clark et al., 2001). Indeed, numerical model experiments show that changing the main meltwater drainage route of the LIS from the Mississippi River to either the northwestern Atlantic Ocean or the Arctic Ocean results in a significant reduction in the AMOC (Maier-Reimer and Mikolajewicz, 1989; Manabe and Stouffer, 1995; Clark et al., 2001; Peltier et al., 2006). However, as the YD is widely viewed as a time of glacial re-advance and reduced terrestrial meltwater discharge to the ocean, it is likely that freshwater forcing was less during this period (Abdul et al., 2016). A similar dichotomy surrounds the cooling during Heinrich Event 1: while this cold stadial was originally hypothesized to have been triggered by icebergs freshening the ocean (Broecker, 1994), recent findings suggest that the cooling might have begun prior to significant ice rafting, such that freshwater forcing (from ice sheets) played a relatively minor role (Barker et al., 2015).

Here, we investigate whether changes in the storage and export of Arctic sea ice to the subpolar North Atlantic played a role in modulating deglacial climate by periodically weakening the overturning cell. While this mechanism was previously proposed by Bradley and England (2008) as trigger for the YD, it has never been explicitly tested. Marine proxies do, however, support the idea that the YD was both a time of increased sea-ice drift and ice export to the subpolar North Atlantic (Not and Hillaire-Marcel, 2012; Müller and Stein, 2014; Müller, 2016). We suspect that additional sea-ice export events also played a role in triggering, or enhancing, other

CITATION: Condron, A., Joyce, A.J., and Bradley, R.S., 2020, Arctic sea ice export as a driver of deglacial climate: Geology, v. 48, p. 395-399, https://doi.org/10.1130/G47016.1 
periods of climate cooling during deglaciation. For example, the drainage of meltwater into the Arctic Ocean as the Cordilleran-Laurentide ice saddle collapsed at ca. $14.5 \mathrm{ka}$ likely created a large ice export event to the North Atlantic that could have enhanced the Older Dryas cooling previously proposed to have been triggered by this meltwater event (Gregoire et al., 2012; Ivanovic et al., 2017). A similar ice export mechanism at ca. $11.3 \mathrm{ka}$ was also proposed to have amplified the climatic cooling during the PBO (Fisher et al., 2002).

More recently, Thornalley et al. (2018) proposed that a similar mechanism might explain the pre-industrial slowdown of the AMOC whereby the enhanced export of sea ice to the Nordic Seas formed during the Little Ice Age had suppressed the sinking limb of the overturning cell. Indeed, modern-day observations and modeling show that changes in Arctic seaice export play an important role in modulating the AMOC (Liu et al., 2019). For example, the Great Salinity Anomaly in the subpolar North Atlantic in the late 1960s and 1970s was caused by a significant increase in the export of Arctic sea ice and is estimated to have weakened the AMOC by 1-3 Sv (Dickson et al., 1988; Zhang and Vallis, 2006). Such ideas thus beg the question of whether the growth of thicker sea ice prior to deglaciation could have generated larger sea-ice export events that were able to keep the AMOC in a weakened state for longer.

\section{METHODS}

We used a combination of historical archives and numerical climate model experiments to estimate past Arctic sea-ice extent and thickness, and the mechanisms altering ice export to the North Atlantic. Initially, we examined the diaries and journals kept by several early $19^{\text {th }}$ and $20^{\text {th }}$ century Arctic expeditions for mentions of encounters with unusually thick sea ice, and any measurements of ice thickness and extent. Descriptions of large Arctic ice islands utilized during the Cold War were also examined to place additional constraints on these parameters. A numerical ocean/sea-ice model (Condron et al., 2009; Hill and Condron, 2014; see the GSA Data Repository ${ }^{1}$ ) was then run to estimate the volume of freshwater that the Arctic Ocean stored as sea ice prior to deglaciation, and to quantify whether deglacial changes in ice export were large enough to slow the AMOC and cool climate.

${ }^{1}$ GSA Data Repository item 2020112, methodological description of the numerical climate model, and vertical profiles of observed and simulated ocean temperature and salinity in the eastern Arctic Basin, is available online at http://www.geosociety.org/ datarepository/2020/, or on request from editing@ geosociety.org.

\section{RESULTS}

Many of the diaries and journals written in the $19^{\text {th }}$ and early $20^{\text {th }}$ centuries provide direct evidence that vast areas of the Arctic Basin were once covered by ice considerably thicker than observed over the past 30-40 years. For instance, in 1875, Sir George Nares (Nares, 1878) introduced the term "palaeocrystic ice," to describe the unique and exceptionally old and thick ice his expedition encountered. This "sea of ancient ice," as he named it, was found to extend along the north coast of Arctic Canada for $>450 \mathrm{~km}$ (Markham, 1878). In other accounts, Cook (1911, p. 266) noted, “... from the $87^{\text {th }}$ to the $88^{\text {th }}$ parallel we passed for 2 days over old ice without pressure lines or hummocks..., but the ice had the hard, wavering surface of glacial ice with only superficial crevasses." At the end of the $19^{\text {th }}$ century, this region of thick Arctic sea ice was estimated to have occupied an area of $\sim 8900 \mathrm{~km}^{2}$ (Vincent et al., 2001), while direct measurements showed that the ice was at least 35-50 m thick (Crary, 1958). Large pieces of thick sea ice were also still being reported in the early $20^{\text {th }}$ century, including one $\sim 25$-km-long and 15 -m-thick on which the Norwegian explorer, Storker Storkerson, spent 6 months adrift (Stefansson, 1921), while similar-sized floes were used as scientific research stations during the Cold War (Walker and Wadhams, 1979; Fig. 1). These regions of thick ice had "long, prairie-like swells" (Peary, 1907, p. 181) typical of modern-day ice shelves, but unlike ice shelves around the Antarctic, this ice was not fed by glaciers. Instead, these regions of ice were composed of sea ice repeatedly thickened by the accumulation of snow and superimposed ice on the surface, as well as the freezing of seawater onto the underside of the ice (Dowdeswell and Jeffries, 2017).

Looking farther back in time, marine sediment records from the central Arctic suggest sea ice continuously covered the Arctic Basin during glacial periods. For example, zero, or near-zero, biomarker concentrations and a hiatus in sediment deposition indicate that during the Last Glacial Maximum (LGM; ca. $18 \mathrm{ka}$ ) the central Arctic Ocean (north of $84^{\circ} \mathrm{N}$ ) was covered by thick permanent sea ice throughout the year, with rare breakup (Polyak et al., 2009; Not and Hillaire-Marcel, 2012; Xiao et al., 2015).
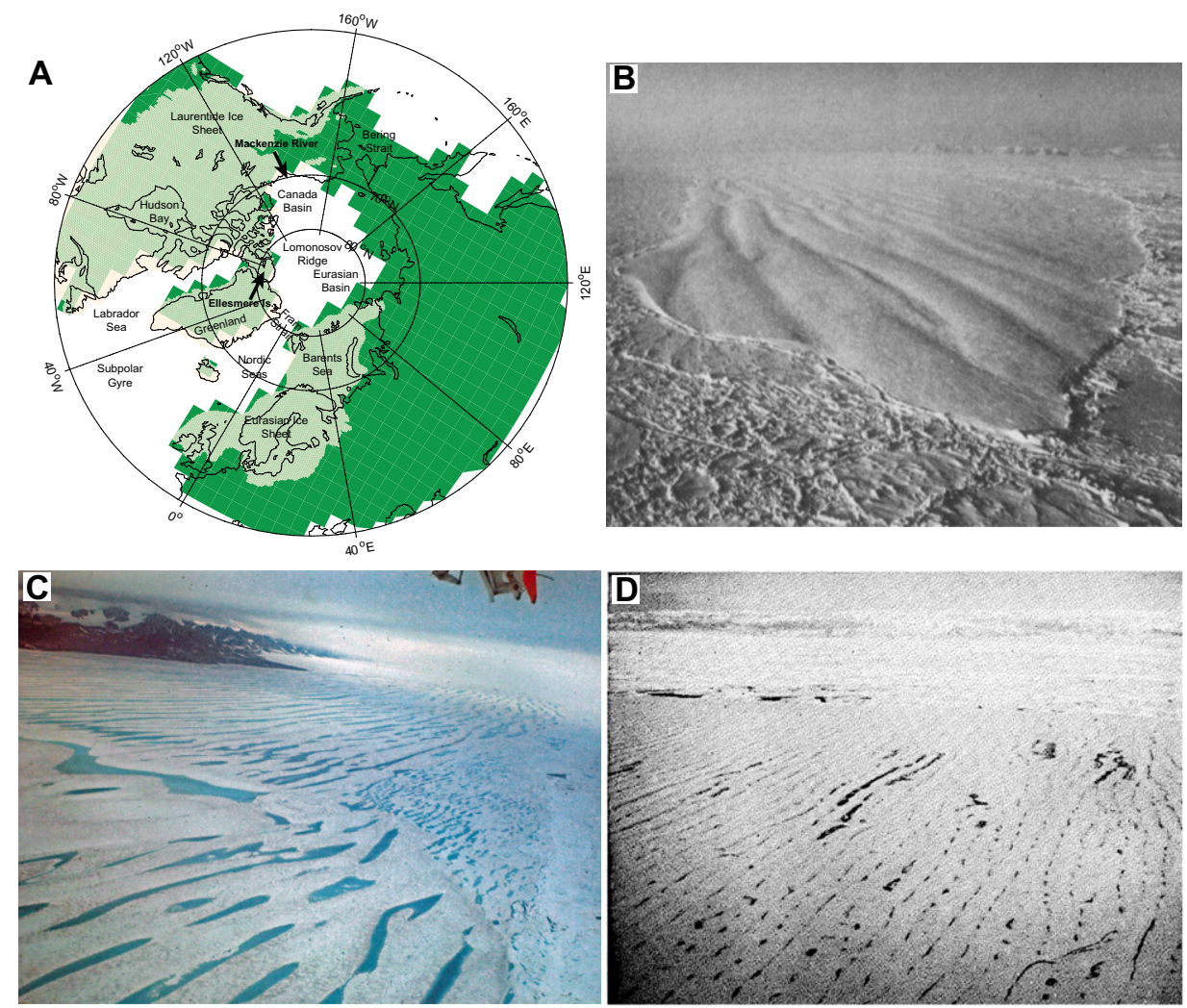

Figure 1. (A) Study location map. Landmasses and major ice sheets during the Last Glacial Maximum (LGM) are shown by the off-white and green shading, respectively. The two black arrows show the locations of Ellesmere Island and the Mackenzie River. (B-D) Photographic evidence of the last remnants of 'palaeocrystic' ice (exceptionally old and thick ice) in the Arctic Ocean. (B) Aerial photograph of Hobson's Choice Ice Island taken in April 1985 (Jeffries, 1992). (C,D) Palaeocrystic ice off the north coast of Ellesmere Island covered by evenly spaced meltwater ponds in 2002 (C) (source: C. Braun, Westfield State University, Massachusetts, USA) and 1951 (D) (source: Koenig et al., 1952, their reference U.S. Air Force, 1951). Although these bodies of ice are tens of meters thick, they are not fed by glaciers. Instead they form in the same way as modern-day sea ice; i.e., by basal freezing and snow accumulation at the surface. 

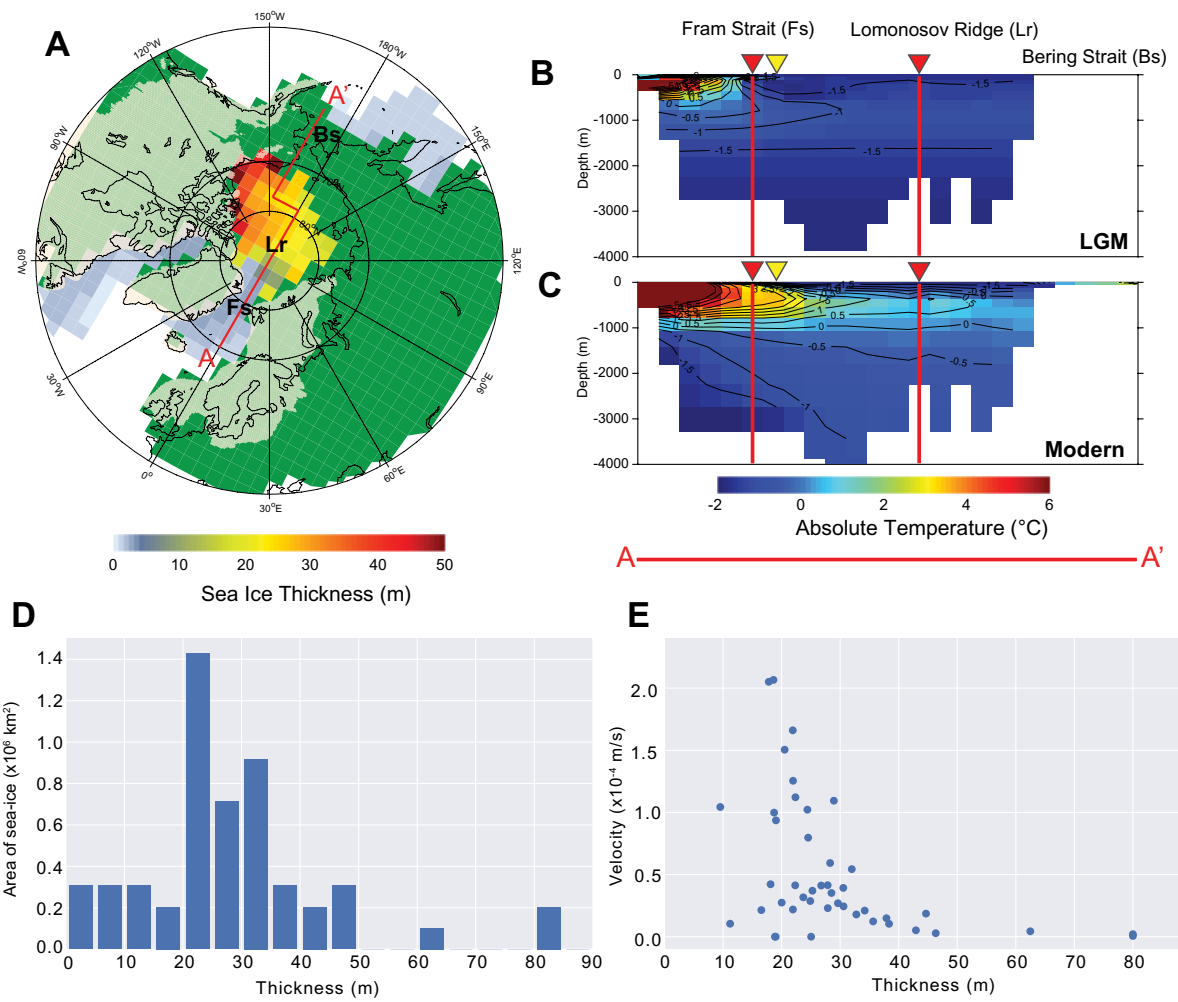

\section{E}

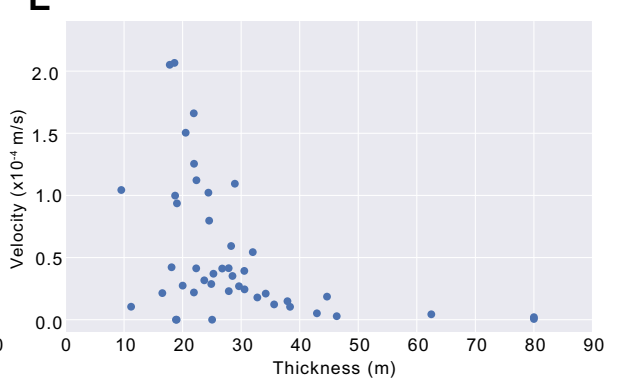

Figure 2. (A) Simulated sea-ice extent and thickness (gray through orange/red shading), prior to ice break-up. Cross section A-A' from Fram Strait to the Bering Strait provides absolute water temperature through the Nordic Seas and Arctic Basin for the Last Glacial Maximum (LGM) (B) and modern day (C). Red triangles in B and C mark the position of Fram Strait and the Lomonosov Ridge, and yellow triangles mark the position of the vertical profiles shown in Figure DR1 (see footnote 1). (D) Histogram of the area of Arctic sea ice of varying thickness, showing that the majority of the basin was covered by $20-30-\mathrm{m}$-thick ice that occupied an area of $\sim 306,000 \mathrm{~km}^{2}$. (E) Ice thickness versus velocity showing that ice velocity reduces with increasing ice thickness.

Our numerical climate model simulation shows that prior to deglaciation, the Arctic basin stored $\sim 140,000 \mathrm{~km}^{3}$ of freshwater (as ice), with an average ice thickness of $26 \mathrm{~m}$ (Fig. 2). For comparison, this volume is $12 \times$ larger than the total amount of meltwater estimated to have been stored in glacial Lake Agassiz at the onset of the YD cold episode (Teller et al., 2002). In agreement with proxy records (Polyak et al., 2009; Xiao et al., 2015), the thickest and most persistent ice in our model is found in the central and western Arctic Ocean, due to the lack of any significant penetration of heat from the Atlantic causing the warm intermediate Atlantic Layer - a pervasive feature across the entire modern Arctic Ocean - to be $\sim 2.5^{\circ} \mathrm{C}$ colder and $500 \mathrm{~m}$ deeper, and restricted to the eastern Arctic (Fig. 2; Fig DR1 in the Data Repository). Ice in the western basin was extremely stagnant ( $<75 \mathrm{~m} / \mathrm{yr}$ ) compared to ice in the eastern Arctic that was much more mobile, and at Fram Strait, where the ice was thinnest $(<10 \mathrm{~m})$, it reached speeds of $\sim 0.05 \mathrm{~m} / \mathrm{s}$ (Figs. $1 \mathrm{E}$ and 2D). Our model also agrees with proxy reconstructions that show that the eastern Nordic Seas were ice-free during the summer, and that during the winter, the sea-ice edge extended south to
Iceland and covered much of the Labrador Sea (Nørgaard-Pedersen et al., 2003; Sarnthein et al., 2003; Fig. DR2). While the thickness of the ice simulated in the central and western Arctic Basin may appear high compared to some existing glacial model simulations (e.g., Li et al., 2010), our results are considerably closer to the thicknesses of the ice described by the $19^{\text {th }}$ century Arctic explorers. In addition, it has become common practice in many model simulations to artificially 'cap' sea-ice thickness to avoid values that are considered (in the scientific community) to be unrealistic for the LGM.

To test whether the mobilization and export of thick Arctic sea ice could have slowed the AMOC, we performed a series of perturbation experiments designed to invigorate sea-ice drift. First, we set the strength of the wind over the transpolar drift to blow constantly in a southerly direction at speeds of either $5 \mathrm{~m} / \mathrm{s}$ or $7.5 \mathrm{~m} / \mathrm{s}$, to simulate the increase in the atmospheric pressure gradient between the Greenland Ice Sheet and Spitzbergen during colder, more glacial periods (Brady et al., 2013). In our initial experiment (ATM5), the perturbation was applied for $5 \mathrm{yr}$ before the winds were returned to the values in the control integration for $50 \mathrm{yr}$. This cycle was then repeated five times. In a second experiment (ATM50), the perturbation was applied for $50 \mathrm{yr}$ before conditions were returned to those in the control for $100 \mathrm{yr}$. In ATM5, wind speeds of $7.5 \mathrm{~m} / \mathrm{s}$ cause $18,500 \mathrm{~km}^{3}$ of sea ice to be released into the Nordic Seas over $5 \mathrm{yr}$, which is double the one-time, $\sim 9,500 \mathrm{~km}^{3}$ discharge of meltwater estimated to have been released from glacial Lake Agassiz at the onset of the YD (Teller et al., 2002; Fig. 3A).

In experiment ATM50, we find a similar but larger response, in which the $7.5 \mathrm{~m} / \mathrm{s}$ wind perturbation causes $\sim 160,000 \mathrm{~km}^{3}$ of ice to be discharged over $50 \mathrm{yr}$, with a peak flux of $\sim 0.15 \mathrm{~Sv}$ that remains sustained at $\sim 0.1 \mathrm{~Sv}$ for $\sim 45 \mathrm{yr}$. Additionally, the $5 \mathrm{~m} / \mathrm{s}$ wind perturbation in this experiment increases sea-ice export after $\sim 20 \mathrm{yr}$, suggesting that the circulation of the central Arctic takes time to 'spin-up' before ice begins to mobilize. Once this event begins, though, sea-ice fluxes of $\sim 0.1 \mathrm{~Sv}$ are generated at Fram Strait, and $\sim 76,000 \mathrm{~km}^{3}$ of freshwater is exported to the Nordic Seas. Compelling evidence that these sea-ice export events directly impact ocean circulation is shown by periods of enhanced ice discharge in both experiments (ATM5 and ATM50) leading to a freshening of the Nordic Seas, a slowdown in the strength of the AMOC, and a reduction in northward heat transport, with the greatest reduction coinciding with the peak in ice export (Fig. 3).

In a second set of perturbation experiments, we simulated the impact of rising sea level submerging the Bering land bridge on sea-ice export. Here, the model shows that the sudden inflow of relatively warm Pacific waters increases both the surface velocity of the Arctic Ocean by $\sim 30 \%$ and the transport of heat into the western Arctic Basin by $1 \mathrm{Tw}\left(\mathrm{Tw}=10^{12}\right.$ watts). This, in turn, causes sea ice in the Canada Basin to mobilize, such that after $\sim 4 \mathrm{yr}$, the export of sea ice through Fram Strait peaks at $\sim 0.1 \mathrm{~Sv}$ (Fig. 4A). Sea-ice discharge then shows a gradual reduction over a period of $\sim 20 \mathrm{yr}$, but continues to be higher than the control integration for the remainder of the simulation. During the first two decades, $\sim 50,000 \mathrm{~km}^{3}$ of sea ice is exported to the North Atlantic, which is more than $5 \times$ the volume of meltwater released from glacial Lake Agassiz at the onset of the YD.

Lastly, we simulated the effect of a glacial outburst flood on the break-up of Arctic sea ice using a higher-resolution, regional configuration of our model (see the Data Repository; Condron et al,. 2009) by releasing glacial meltwater from the Mackenzie River in the western Arctic for $1 \mathrm{yr}$. Here, we find that after just 3 months, the export of ice at Fram Strait peaks at $\sim 0.4 \mathrm{~Sv}$, as thick $(>10 \mathrm{~m})$ ice moves from the western Arctic to the Nordic Seas at speeds of up to $0.5 \mathrm{~m} / \mathrm{s}$ (Fig. 4B). The ice then drifts south in the East Greenland Current and provides freshwater to regions of deepwater formation in the subpolar 


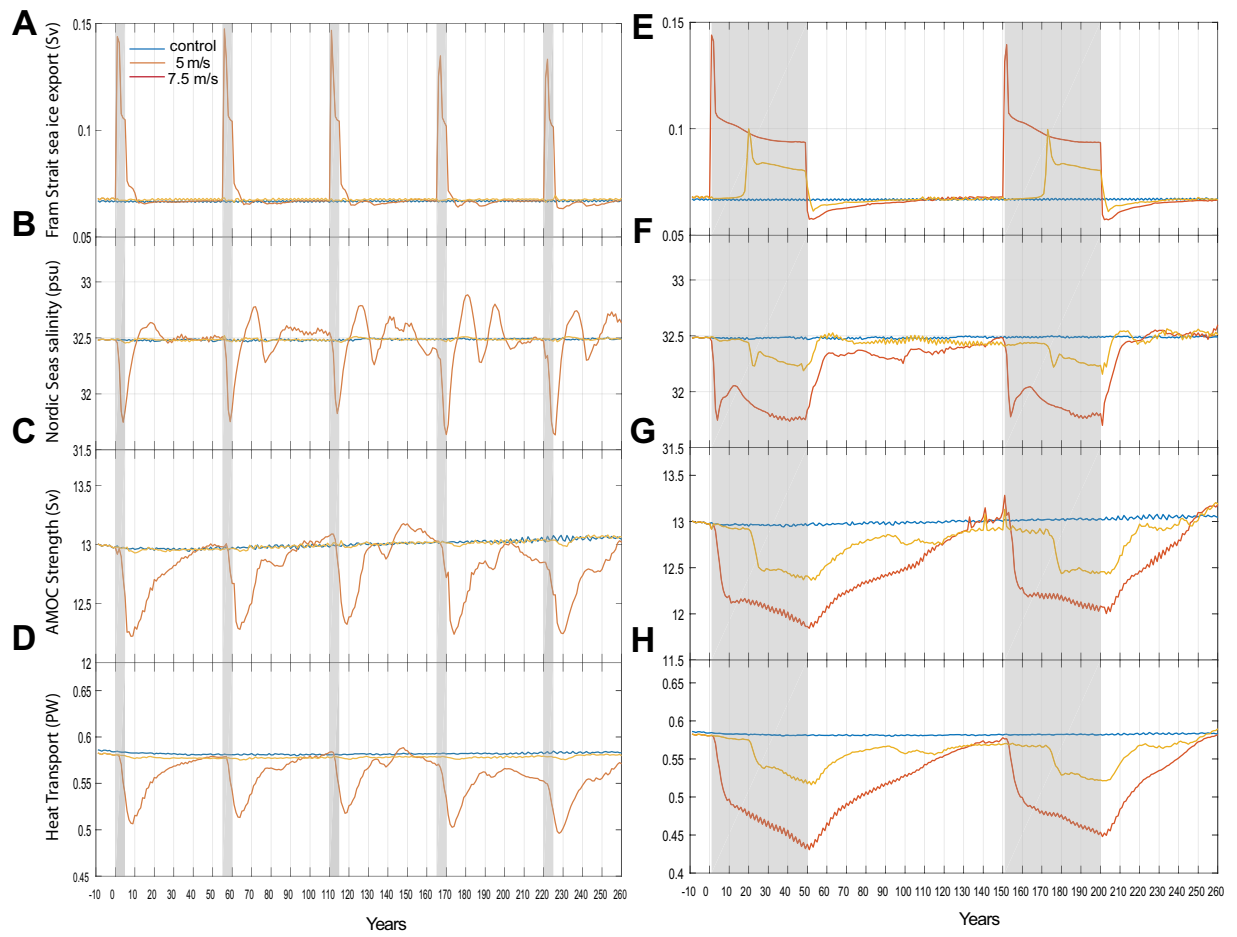

Figure 3. The response of Arctic sea ice at Fram Strait, and ocean circulation to the mobilization of ice in the central Arctic Basin in experiments ATM5 (A-D) and ATM50 (E-H). Sv = $10^{6} \mathrm{~m}^{3} / \mathrm{s}$. Each time the transpolar drift is enhanced by the wind perturbation (gray shading; wind speed of $5 \mathrm{~m} / \mathrm{s}$ [orange] or $7.5 \mathrm{~m} / \mathrm{s}$ [red]), sea-ice export to the central Nordic Seas increases $(A, E)$, the Nordic Seas freshen $(B, F)$, the strength of the Atlantic Meridional Overturning circulation $(A M O C)$ weakens $(C, G)$, and the northward transport of heat is reduced $\left(D, H ; 1 P W=10^{15} W\right)$.

\section{A}

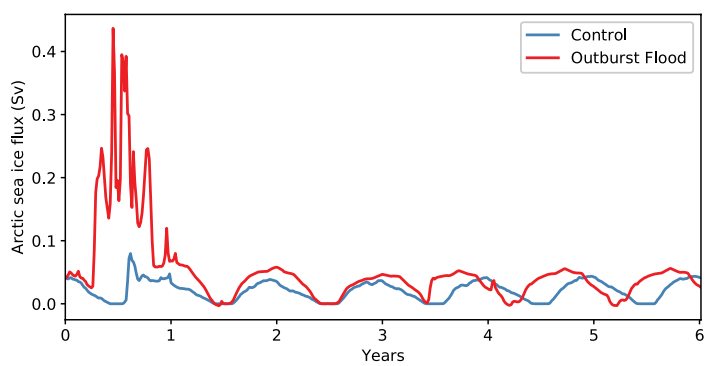

B
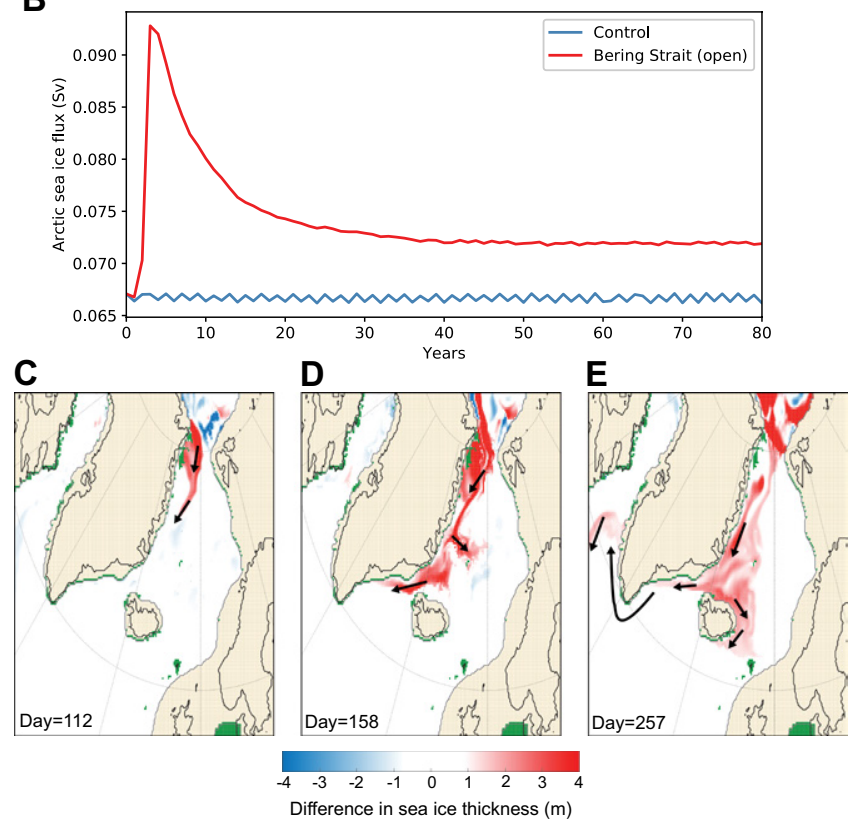

North Atlantic (Figs. 4C-4E). Significantly, this flux of freshwater (as ice) is over $4 \times$ that required to weaken the AMOC in many numerical climate models (e.g., Stouffer et al., 2006).

\section{CONCLUSIONS}

Our results show that the thick 'palaeocrystic ice' Sir George Nares reported in the Arctic Ocean over 140 years ago during the British Arctic Expedition (Nares, 1878) would likely have covered much of the Arctic Basin prior to deglaciation, creating an enormous reservoir of freshwater, independent from terrestrial sources. The periodical export of this sea ice through Fram Strait produces several large freshwater discharge events that, in our model, exceed the estimated volumes of freshwater released from glacial Lake Agassiz as a result of a drawdown in lake level, and are large enough to slow the AMOC. We expect that feedbacks in the climate system that are not fully resolved in our model would have resulted in the exported sea ice lowering the surface air temperatures over the subpolar North Atlantic to promote additional ice growth and prolonged cooling. Such conditions may have been maintained for several centuries until the ice finally melted. Our findings thus highlight that the build-up and export of Arctic sea ice likely played an important role in triggering, or enhancing, deglacial cooling periods such as the Older Dryas, Younger Dryas, and the PBO.

\section{ACKNOWLEDGMENTS}

The research was supported by the National Science Foundation (NSF) through NSF grants ARC-1204045 and PLR-1417667. The numerical simulations were carried out using MITgcm (http://mitgcm.org) and used resources provided by the Extreme Science and Engineering Discovery Environment (XSEDE; https:// www.xsede.org), which is supported by NSF grant number ACI-1053575.

\section{REFERENCES CITED}

Abdul, N.A., Mortlock, R.A., Wright, J.D., and Fairbanks, R.G., 2016, Younger Dryas sea level and meltwater pulse 1B recorded in Barbados reef crest coral Acropora palmata: $\mathrm{Pa}-$ leoceanography, v. 31 , p. $330-344$, https://doi .org/10.1002/2015PA002847.

Alley, R.B., 2000, The Younger Dryas cold interval as viewed from central Greenland: Quaternary Science Reviews, v. 19, p. 213-226, https://doi .org/10.1016/S0277-3791(99)00062-1.

Baldini, J.U., Brown, R.J., and Mawdsley, N., 2018, Evaluating the link between the sulfur-rich Laacher See volcanic eruption and the Younger Dryas climate anomaly: Climate of the Past, v. 14, p. 969-990, https://doi.org/10.5194/cp-14-9692018.

Barker, S., Chen, J., Gong, X., Jonker, L., Knorr, G., and Thornalley, D., 2015, Icebergs not the trigger for North Atlantic cold events: Nature, v. 520, p. 333-336, https://doi.org/10.1038/nature14330.

Bradley, R.S., and England, J.H., 2008, The Younger Dryas and the Sea of Ancient Ice: Quaternary Research, v. 70, p. 1-10, https://doi.org/10.1016/ j.yqres.2008.03.002.

Brady, E.C., Otto-Bliesner, B.L., Kay, J.E., and Rosenbloom, N., 2013, Sensitivity to glacial 
forcing in the CCSM4: Journal of Climate, v. 26, p. 1901-1925, https://doi.org/10.1175/ JCLI-D-11-00416.1.

Broecker, W.S., 1994, Massive iceberg discharges as triggers for global climate change: Nature, v. 372, p. 421-424, https://doi.org/10.1038/372421a0.

Broecker, W.S., 2006, Was the Younger Dryas triggered by a flood?: Science, v. 312, p. 1146-1148, https://doi.org/10.1126/science.1123253.

Broecker, W.S., Kennett, J.P., Flower, B.P., Teller, J.T., Trumbore, S., Bonani, G., and Wolfli, W., 1989 , Routing of meltwater from the Laurentide Ice Sheet during the Younger Dryas cold episode: Nature, v. 341, p. 318-321, https://doi .org/10.1038/341318a0

Condron, A., Winsor, P., Hill, C., and Menemenlis, D., 2009, Simulated Response of the Arctic Freshwater Budget to Extreme NAO Wind Forcing: Journal of Climate, v. 22, p. 2422-2437, https:// doi.org/10.1175/2008JCLI2626.1.

Cook, F., 1911, My Attainment of the Pole: New York, Polar Publishing Company, $604 \mathrm{p}$.

Clark, P.U., Marshall, S.J., Clarke, G.K., Hostetler, S.W., Licciardi, J.M., and Teller, J.T., 2001, Freshwater forcing of abrupt climate change during the last glaciation: Science, v. 293, p. 283 287, https://doi.org/10.1126/science.1062517.

Crary, A.P., 1958, Arctic Ice Island and ice shelf studies, Part 1: Arctic, v. 11, p. 2-42, https://doi .org/10.14430/arctic3731

Dowdeswell, J., and Jeffries, M.O., 2017, Arctic ice shelves: An introduction, in Copeland L., and Mueller, D., eds., Arctic Ice Shelves and Ice Islands: Springer Polar Sciences, p. 3-21, https:// doi.org/10.1007/978-94-024-1101-0_1.

Dickson, R.R., Meincke, J., Malmberg, S.A., and Lee, A.J., 1988, The "great salinity anomaly" in the northern North Atlantic 1968-1982: Progress in Oceanography, v. 20, p. 103-151, https://doi .org/10.1016/0079-6611(88)90049-3.

Eisenman, I., Bitz, C.M., and Tziperman, E., 2009, Rain driven by receding ice sheets as a cause of past climate change: Paleoceanography, v. 24, PA4209, https://doi.org/10.1029/2009PA001778.

Firestone, R.B., et al., 2007, Evidence for an extraterrestrial impact 12,900 years ago that contributed to the megafaunal extinctions and the Younger Dryas cooling: Proceedings of the National Academy of Sciences of the United States of America, v. 104, p. 16016-16021, https://doi.org/10.1073/ pnas.0706977104.

Fisher, T.G., Smith, D.G., and Andrews, J.T., 2002, Preboreal oscillation caused by a glacial Lake Agassiz flood: Quaternary Science Reviews, v. 21, p. 873-878, https://doi.org/10.1016/S02773791(01)00148-2.

Gregoire, L.J., Payne, A.J., and Valdes, P.J., 2012, Deglacial rapid sea level rises caused by ice-sheet saddle collapses: Nature, v. 487, p. 219-222, https://doi.org/10.1038/nature11257.

Hill, J.C., and Condron, A., 2014, Subtropical iceberg scours and meltwater routing in the deglacial western North Atlantic: Nature Geoscience, v. 7, p. 806-810, https://doi.org/10.1038/ ngeo 2267

Ivanovic, R.F., Gregoire, L.J., Wickert, A.D., Valdes, P.J., and Burke, A., 2017, Collapse of the North American ice saddle 14,500 years ago caused widespread cooling and reduced ocean overturning circulation: Geophysical Research Letters, v. 44, p. 383-392, https://doi .org/10.1002/2016GL071849.
Jeffries, M.O., 1992, Arctic ice shelves and ice islands: Origin, growth and disintegration, physical characteristics, structural-stratigraphic variability, and dynamics: Reviews of Geophysics, v. 30 p. 245-267, https://doi.org/10.1029/92RG00956.

Kennett, J.P., and Shackleton, N.J., 1975, Laurentide ice sheet meltwater recorded in Gulf of Mexico deep-sea cores: Science, v. 188, p. 147-150, https://doi.org/10.1126/science.188.4184.147.

Koenig, L.S., Greenaway, K.R., Dunbar, M., and Hattersley-Smith, G., 1952, Arctic ice islands: Arctic, v. 5, p. 66-103, https://doi.org/10.14430/ $\operatorname{arctic} 3901$.

Li, C., Battisti, D.S., and Bitz, C.M., 2010, Can North Atlantic sea ice anomalies account for Dansgaard-Oeschger climate signals?: Journal of Climate, v. 23, p. 5457-5475, https://doi .org/10.1175/2010JCLI3409.1.

Liu, W., Fedorov, A., and Sévellec, F., 2019, The mechanisms of the Atlantic meridional overturning circulation slowdown induced by Arctic sea ice decline: Journal of Climate, v. 32, p. 977-996, https://doi.org/10.1175/JCLI-D-18-0231.1.

Maier-Reimer, E., and Mikolajewicz, U., 1989, Experiments with an OGCM on the cause of the Younger Dryas: Hamburg, Max-Planck-Institut für Meteorologie, Report 39, p. 1-13.

Markham, A.H., 1878, The Great Frozen Sea: A Personal Narrative of the Voyage of the" Alert" During the Arctic Expedition of 1875-6: London, Kegan Paul, Trench, Trübner \& Co., Ltd., 440 p.

Manabe, S., and Stouffer, R.J., 1995, Simulation of abrupt climate change induced by freshwater input to the North Atlantic Ocean: Nature, v. 378, p. 165-167, https://doi.org/10.1038/378165a0.

Meissner, K.J., and Clark, P.U., 2006, Impact of floods versus routing events on the thermohaline circulation: Geophysical Research Letters, v. 33 L15704, https://doi.org/10.1029/2006GL026705.

Müller, J., and Stein, R., 2014, High-resolution record of late glacial and deglacial sea ice changes in Fram Strait corroborates ice-ocean interactions during abrupt climate shifts: Earth and Planetary Science Letters, v. 403, p. 446-455, https://doi .org/10.1016/j.epsl.2014.07.016

Müller, J., 2016, New evidence for abrupt sea-ice fluctuations in the subpolar North Atlantic at the end of the Last Glacial in relation with thermohaline and atmospheric circulation: Polarforschung, v. 85 , p. $157-160$, https://doi.org/10.2312/polfor.2016.012

Murton, J., Bateman, M.D., Dallimore, S.R., Teller, J.T., and Yang, Z., 2010, Identification of Younge Dryas outburst flood path from Lake Agassiz to the Arctic Ocean: Nature, v. 464, p. 740-743, https://doi.org/10.1038/nature08954.

Muschitiello, F., Lea, J.M., Greenwood, S.L. Nick, F.M., Brunnberg, L., MacLeod, A., and Wohlfarth, B., 2016, Timing of the first drainage of the Baltic Ice Lake synchronous with the onset of Greenland Stadial 1: Boreas, v. 45, p. 322-334, https://doi.org/10.1111/bor.12155.

Nares, G., 1878, Narrative of a Voyage to the Polar Sea During 1875-6 in HM Skips Alert Discovery: London, Sampson Low, Marston, Searle, \& Rivington, $378 \mathrm{p}$.

Not, C., and Hillaire-Marcel, C., 2012, Enhanced seaice export from the Arctic during the Younger Dryas: Nature Communications, v. 3 , p. 647 , https://doi.org/10.1038/ncomms1658.

Nørgaard-Pedersen, N., Spielhagen, R.F., Erlenkeuser, H., Grootes, P.M., Heinemeier, J., and
Knies, J., 2003, Arctic Ocean during the Last Glacial Maximum: Atlantic and polar domains of surface water mass distribution and ice cover: Paleoceanography, v. 18, p. 1-19, https://doi org/10.1029/2002PA000781.

Peary, R.E., 1907, Nearest the Pole: A narrative of the polar expedition of the Peary Arctic Club in the SS Roosevelt, 1905-1906: New York, Doubleday, p. 1907.

Peltier, W.R., Vettoretti, G., and Stastna, M., 2006, Atlantic meridional overturning and climate response to Arctic Ocean freshening: Geophysical Research Letters, v. 33, p. L06713, https://doi .org/10.1029/2005GL025251.

Polyak, L., et al., 2009, Late Quaternary stratigraphy and sedimentation patterns in the western Arctic Ocean: Global and Planetary Change, v. 68, p. 5-17, https://doi.org/10.1016/ j.gloplacha.2009.03.014.

Renssen, H., Mairesse, A., Goosse, H., Mathiot, P., Heiri, O., Roche, D.M., Nisancioglu, K.H., and Valdes, P.J., 2015, Multiple causes of the Younger Dryas cold period: Nature Geoscience, v. 8, p. $946-949$, https://doi.org/10.1038/ngeo 2557

Sarnthein, M., Pflaumann, U., and Weinelt, M., 2003, Past extent of sea ice in the northern North Atlantic inferred from foraminiferal paleotemperature estimates: Paleoceanography, v. 18, https://doi org/10.1029/2002PA000771.

Stefansson, V., 1921, The Friendly Arctic: The story of Five Years in Polar Regions: London: Macmillan and Co., Ltd., 784 p.

Stouffer, R.J., et al., 2006, Investigating the causes of the response of the thermohaline circulation to past and future climate changes: Journal of Climate, v. 19, p. 1365-1387, https://doi .org/10.1175/JCLI3689.1.

Teller, J.T., Leverington, D.W., and Mann, J.D., 2002, Freshwater outbursts to the oceans from glacial Lake Agassiz and their role in climate change during the last deglaciation: Quaternary Science Reviews, v. 21, p. 879-887, https://doi.org/10.1016/ S0277-3791(01)00145-7.

Thornalley, D.J., Oppo, D.W., Ortega, P., Robson, J.I., Brierley, C.M., Davis, R., Hall, I.R., MoffaSanchez, P., Rose, N.L., Spooner, P.T., and Yashayaev, I., 2018, Anomalously weak Labrador Sea convection and Atlantic overturning during the past 150 years: Nature, v. 556, p. 227-230, https://doi.org/10.1038/s41586-018-0007-4.

Vincent, W.F., Gibson, J.A.E., and Jeffries, M.O., 2001, Ice shelf collapse, climate change and habitat loss in the Canadian High Arctic: The Polar Record, v. 37, p. 133-142, https://doi .org/10.1017/S0032247400026954.

Walker, E.R., and Wadhams, P., 1979, Thick SeaIce Floes: Arctic, v. 32, p. 140-147, https://doi org/10.14430/arctic2612.

Wunsch, C., 2006, Abrupt climate change: An alternative view: Quaternary Research, v. 65, p. 191203, https://doi.org/10.1016/j.yqres.2005.10.006.

Xiao, X., Stein, R., and Fahl, K., 2015, MIS 3 to MIS 1 temporal and LGM spatial variability in Arctic Ocean sea ice cover: Reconstruction from biomarkers: Paleoceanography, v. 30, p. 969-983, https://doi.org/10.1002/2015PA002814.

Zhang, R., and Vallis, G.K., 2006, Impact of great salinity anomalies on the low-frequency variability of the North Atlantic Climate: Journal of Climate, v. 19, p. 470-482, https://doi.org/10.1175/JCLI3623.1.

Printed in USA 